\title{
NATIONALIZATION OF FOREIGN OWNED PROPERTY AND THE ACT OF STATE DOCTRINE-TWO SPEECHES
}

7 HE recent nationalization of an estimated one billion dollars in

American owned property in Cuba has given rise to a myriad of cases in the state and federal courts of this country. At the behest of the American Foreign Law Association, and at their January 1963 meeting in New York City, Professors Baade and Domke discussed these cases and particularly the controversial Act of State doctrine. The remarks of these outstanding experts on the law of nationalization of property are printed here without revision, except for documentation.

\section{THE PRESENT AMERICAN ATTITUDE TOWARDS NATIONALIZATION OF FOREIGN-OWNED PROPERTY}

\author{
MARTIN Domke*
}

$W_{\text {hen Americans currently talk or write about foreign nationaliza- }}$ tion problems, they are primarily concerned with the Cuban situation where, for all practical purposes, only American interests are involved. This was not the case with other foreign nationalizations of the recent past, such as the Iranian oil expropriation in 1952, the Egyptian nationalization of the Suez Canal in 1956, and the Indonesian expropriation of Dutch property in 1958. Other expropriations of American interests occurred in some Latin American countries and are in the making in Asia and Africa. Refined techniques are developing in the field of expropriation abroad. There are many forms of creeping nationalization, discriminatory administration and violation of contractual rights of foreign parties. This

\footnotetext{
- Dr. jur. 1915, University of Greifswald, Germany; Adj. Associate Professor of Law, New York University; Editor-in-Chief, The ARbItratron Journal. Member, Executive Council, American Society of International Law; Executive Committee, American Branch, International Law Association; Director, American Foreign Law Association and Consular Law Society. Contributor to American and foreign legal periodicals.
} 
is especially true with regard to American stockholder interests in foreign corporations: dissolution of the corporation, appropriation merely of its own assets, and sometimes the confiscation of shares. All these issues create difficult questions of application of foreign corporation law with which American courts are faced.

An example of this question is the recent doubt of New York courts on whether the Cuban nationalization of American property rights constitutes nationalization at all within the meaning of section 977(b) of the Civil Practice Act. New York law provides for the appointment of a receiver for the administration of assets of foreign corporations which are dissolved, liquidated, nationalized, or have ceased to do business. Now, the Cuban Law No. 851, of August 6, 1960, provides for the nationalization of Cuban corporations in which Americans were the controlling stockholders. In Schwartz $v$. Compania Azucarera Vertientes-Camaquey de Cuba, ${ }^{1}$ Judge Baker of the New York Supreme Court vacated a receivership on the ground that the law only nationalized the assets of the Cuban corporation and left the juridic personality of the company in existence, entitled to later compensation, and thus also to be able to do business abroad. In another decision, on November 15, 1962, ${ }^{2}$ the Appellate Division allowed the Cuban government to intervene in an action of the New York stockholders under section 977(b) of the Civil Practice Act, leaving it doubtful "if indeed they [the powers conferred upon the intervenor by the Cuban decree] are found to be confiscatory."3

That the American attitude towards foreign nationalizations has become somewhat confused can be shown by reading the notes on the decision of March 31, 1961, of District Judge Dimock in Banco Nacional de Cuba v. Sabbatino. ${ }^{4}$ Briefly, the Sabbatino case concerns a situation where a New York broker bought sugar from a Cuban corporation of which more than 90 per cent was controlled by American stockholders. The sugar was loaded on a ship in a Cuban harbor when the Cuban nationalization law was issued on August

\footnotetext{
1148 N.Y.L.J., Sept. 21, 1962, p. 13, col. 6; 149 Ibid., Mar. 14, 1963, p. 17, col. 7.

2 Mann v. Compania Petrolera Trans-Cuba S.A., 17 App. Div. 2d 193, 234 N.X.S.2d 1001 (1962).

2234 N.Y.S.2d at 1005.

193 F. Supp. 375 (S.D.N.Y. 1961). No less than 19 notes have treated this case, the most recent ones are 75 HARv. L. REv. 1607 (1962) and 62 ColUM. L. REv. 1278 (1962).
} 
6,1960 . The sugar was undoubtedly within the territorial limits of Guba at the time of the nationalization. In order to get the cargo, the New York brokerage firm made similar contracts with an agency of the Cuban government, Banco para el Comercio Exterior de Cuba. The seller assigned the claim to the Banco Nacional de Cuba, which asked for the sale proceeds in the New York action. Meanwhile, on August 16,1960, a receiver had been appointed in the person of Mr. Sabbatino, who deposited the money with the New York Trust Company under the supervision of the court. 5

Both the District Court and the Second Circuit Court of Appeals ${ }^{6}$ dismissed the complaint on the ground that plaintiff's claim of title depended on the validity of the Cuban nationalization law and that this Cuban law would not be recognized and enforced in this country because it violated international law.

The international law of foreign nationalization has unfortunately been cast into some confusion. Court decisions of various countries, not only those of the United States, fail to contribute decisively to a clarification of the important issues involved. This kind of confusion or uncertainty becomes evident in the recent resolution of the U.N. General Assembly on sovereign immunity over natural resources. ${ }^{7}$ Its article 4 reads as follows:

Nationalization, expropriation or requisitioning shall be based on grounds or reasons of public utility, security or the national interest which are recognized as overriding purely individual or private interests, both domestic and foreign. In such cases the owner shall be paid appropriate compensation, in accordance with the rules in force in the State taking such measures in the exercise of its sovereignty and in accordance with international law. In any case, where the question of compensation gives rise to a controversy, the national jurisdiction of the State taking such measures shall be exhausted. However, upon agreement by sovexeign States and other parties concerned, settlement of the dispute should be made through arbitration or international adjudication.

The wording was adopted after twenty-six amendments had been considered, among them one sponsored by the United States, to substitute for "appropriate compensation" the words "prompt, adequate and effective." It remains undetermined which law prevails

\footnotetext{
- Schwartz v. Compania Azucarera Vertientes-Camaguey de Cuba, 12 App. Div. 2d 506, 207 N.Y.S.2d 288 (1960).

○ 307 F.2d 845 (2d Cir. 1962), cert. granted, 31 U.S.L. WEEK 3259 (Feb. 18, 1962).

7 U.N. Doc. No. A/RES/1803 (XVII) (Dec. 19, 1962).
} 
on the question of compensation-the domestic law of the expropriating country, or international law.

Another interesting expression of the American attitude is the recent legislative enactment of Section 630(e) of the Foreign Assistance Act of 1962.8 There, the President is required in a mandatory way to suspend any aid to a country which, in an expropriation after January 1, 1962, has not taken "appropriate steps, which may include arbitration, to discharge its obligations under international law toward such [American] citizen or entity, including equitable and speedy compensation for such property in convertible foreign exchange, as required by international law." 9 This threat of discontinuing foreign aid may play a decisive role in negotiations with Brazil and Ceylon on compensation for expropriated American interests.9a Unfortunately this aspect of expropriation without compensation was not determined by Circuit Judge Waterman in the Sabbatino case: "Whether a government's failure, in and of itself, to pay adequate compensation for the property it takes is a breach of international responsibility, we decline at this time to attempt a resolution of that difficult question."10 Suffice it to note here what the Secretary of State, Dean Rusk, recently said at a meeting of the National Business Advisory Council: "Any sovereign national has the right to expropriate property, whether owned by foreigners or nationals. In the United States we refer to this as the power of eminent domain. However, the owner should receive adequate and prompt compensation for his property."11

We now observe a curious interplay of the executive and judicial authority to determine the effect of foreign nationalization on American property rights. One should not lose sight of the basic fact that this is less a political question than one of monetary interest to the American taxpayer whose property rights in foreign investments abroad have to be safeguarded. In this field there is great confusion regarding two concepts of international law: immunity and the Act of State doctrine. Briefly, immunity concerns the exemption of a foreign state from the jurisdiction of other coun-

76 Stat. 260, 22 U.S.C.A. $\$ 2370$ (e) (1962).

- Ibid.

ox Meanwhile, the United States foreign assistance program was suspended in Ceylon on Feb. 8, 1963. See 109 Conc. Rec. 2019 (Feb. 11, 1963).

10307 F.2d at 864.

11 Press Release of the State Department No. 633, Oct. 19, 1962, p. 11. 
tries, immunity ratione personae. The Act of State doctrine is based on an immunity ratione materiae, namely that the foreign judge should not be allowed to review the acts of another sovereign which were done within the latter's territory.

An example of the confusion is the case of Pons $v$. Republic of Cuba. ${ }^{12}$ There, a former official of the Cuban government had in his possession about $\$ 56,000$ which he undoubtedly had to return to the Cuban government. In an action of the Cuban government, he made a counterclaim for compensation for the value of his property which was confiscated in Cuba. The courts dismissed this counterclaim, the Court of Appeals stating the rule "that a foreign sovereign's seizure of its own national's property in its own territory cannot be reviewed in our courts."13

An interesting incident in this case was the fact that the court "invited the Department of Justice and the Department of State to file briefs, if they should see fit, expressing their views on any issues or question of interest to them in this case."14 No briefs were filed.

It may be that our government felt that it did not have to give any expression of its views on Cuban nationalizations, since a Cuban national and not a American was involved. Generally, the relationship of a national to its own government is not a question of international law. On the other hand, the Fifth Circuit Court of Appeals held, in the recent decision of Rodriguez $v$. Pan American Life Insurance Company, ${ }^{15}$ where Cuban exiles were allowed to institute a law suit against a Louisiana insurance company: "It matters not whether the thrust of those [Cuban] decrees be directed against Cuban nationals or American citizens."16

Immunity is not involved if the government itself sues in the courts of this country. This is the case in Banco Nacional de Cuba v. Sabbatino, ${ }^{17}$ where the Cuban government claimed the proceeds of the sugar sale through its bank. Immunity only plays a role where the foreign government or its agency is the respondent in a law suit. The courts in this country are generally inclined to accept a sug-

${ }^{22} 294$ F.2d 925 (D.C. Gir. 1961), cert. denied, 368 U.S. 960 (1962).

18294 F.2d at 926.

14 Ibid.

${ }^{26} 311$ F.2d 429 (1962), petition for cert. filed, 31 U.S.L. WeER 3284 (U.S. Mar. 5, 1963) (No. 792-93).

${ }^{10} I d$. at 436.

${ }^{17} 193$ F. Supp. 375 (S.D.N.Y. 1961), aff'd, 307 F.2d 845 (2d Cir. 1962). 
gestion by the State Department of immunity of the foreign government as conclusive and will dismiss the claim against the foreign government for lack of jurisdiction..$^{18}$

An exception to this acceptance of the State Department's suggestion can be found in the Czechoslovakian nationalization cases which were decided by the New York Court of Appeals as recently as November 1, 1962.19 There the court, in affirming the decisions below, considered the suggestion of the State Department as outside of the usual function when the suggestion of immunity thereby tried to determine title to assets of a foreign nationalized bank.

As far as the immunity concept is recognized in Cuban matters, the famous case of Rich $v$. Naviera Vacuba ${ }^{20}$ may be mentioned. There, the merchant vessel Bahia de Nipe, owned by the Cuban government, came to Norfolk where the captain and the crew sought political refuge. One libelant, the United Fruit Company, claimed that the cargo of sugar had been unlawfully confiscated by the Cuban government. All courts unanimously agreed on the immunity of the Cuban government, after the State Department suggested a release of the ship and its cargo. ${ }^{21}$

Confusion also exists in this field of sovereign immunity of the Cuban government, since the United States has severed diplomatic relations with it. In Dade Drydock Corp. v. The M/T Mar Caribe, ${ }^{22}$ the court held, without advice by the State Department, that the Cuban government was not entitled to sovereign immunity until the resumption of normal diplomatic relations.

In another Cuban case, ${ }^{23}$ the question arose whether plaintiff, a banking firm existing under Cuban law and an agent or instrumentality of the Guban government, might sue for loss resulting from the failure of the Liberian shipping company, owner of S. S.

\footnotetext{
${ }^{18} \mathrm{Cf}$., the recent article by John Norton Moore, The Role of the State Department in Judicial Proceedings, 31 FORDHAM L. REv. 277 (1962).

${ }^{10}$ Stephen v. Zivnostenska Banka, 12 N.Y.2d 781, 186 N.E.2d 676, 235 N.Y.S.2d 1 (1962); Wolchok v. Statni Banka Ceskoslovenska, 12 N.Y.2d 784, 186 N.E.2d 678, 295 N.Y.S.2d 3 (1962).

20197 F. Supp. 710 (E.D. Va.), aff'd, 295 F.2d 24 (4th Cir. 1961).

${ }^{21}$ The briefs filed before the Chief Justice of the United States Supreme Court in petitions for stay of execution, are published in 1 INTERNamional Legal Materials 276. These petitions were ultimately unsuccessful. See also 50 CALIF. L. REv. 559 (1962).

22199 F. Supp. 871 (S.D. Texas 1961).

ss $P$ \& E Shipping Corp. v. Banco Para El Comercio Exterior de Cuba, 307 F.2d 415 (1st Cir. 1962), cert. granted, 81 U.S.L. WEEK 3255 (U.S. Feb. 19, 1968) (No. 403).
} 
Ruth Ann, to deliver a cargo of beans. The court remanded the case to the district court, with instructions to ascertain from the State Department "what is the status of the Republic of Cuba as a state and its right to sue in our courts during the period of cessation of diplomatic relations." 24

Uncertainty also exists in the field of sovereign immunity, especially whether transactions of the foreign government are of a commercial character so that the restricted concept of the so-called Tate Letter ${ }^{25}$ becomes applicable. A foreign government acting jure gestionis (not jure imperii) should not be authorized to claim immunity from American jurisdiction. Thus, in Harris of Co. Advertising $v$. Republic of $\mathrm{Cuba},{ }^{26}$ where the respondent had not obtained a suggestion for immunity from the State Department, the court reversed, holding that the contract for the promotion of tourist trade to Cuba was of a commercial character. This was followed in Three Stars Trading Co. $v$. Republic of Cuba. ${ }^{27}$ In that case of a breach of a contract for the sale of frozen shrimp by the Cuban Department of Fisheries, the court said: "If Cuba is permitted to collect dollars on its commercial activities it must respond in our courts on its commercial contracts."28

The confusion regarding the concepts of immunity and also of the Act of State doctrine-the latter to be discussed instantly-led Senator Ervin to introduce a bill to provide means of redress for the unlawful seizure of American property by foreign governments. The bill provides as follows:

If the matter in controversy in any such action involves, or arises out of, an act of a foreign state in violation of general principles of international law, or of a treaty to which the United States and the foreign state are signatories, it shall be no bar to the maintenance of the action that it is brought against a sovereign state, without its consent, or that it involves the validity of official acts of such state. ${ }^{29}$

Mind the last words: "official acts of such state." This is the basic issue in the forefront of judicial determination when American interests are affected by foreign nationalizations. Here, the Act of

\footnotetext{
24 Id. at 418 .

2826 Dept. State Buld. 984 (1952).

20 127 So. 2d 687 (Fla. Dist. Ct. App. 1961).

2732 Misc. 2d 4, 222 N.Y.S.2d 675 (1961).

${ }^{28}$ Id. at 6,222 N.Y.S.2d at 678.

s. 3795, 87th Cong., 2d Sess. (Oct. 5, 1902).
} 
State doctrine is challenged, namely whether the American judge should be free to adjudicate the effect of foreign nationalizations when the latter are in violation of international law. In other words, are exceptions possible from the application of the Act of State doctrine? This issue was raised in recent decisions regarding the Indonesian nationalization of Dutch tobacco in Dutch and German courts, granting such an exception (Court of Appeals, Amsterdam), and denying it (Court of Appeals, Bremen). ${ }^{30}$

In the United States, both Judge Dimock and Judge Waterman in the Sabbatino case considered the Cuban nationalization of American property interests in violation of international law and therefore held the Act of State doctrine not applicable.

It is generally accepted that this doctrine is not a rule of international law. Therefore, as the Restatement of the Foreign Relations Law of the United States, Proposed Official Draft, said: "Refusal to apply it [Act of State dotcrine] does not give the foreign state, whose acts of state are either questioned or denied effect, a ground for objection under international law." 31 And in a Caveat to section 43 , it is said:

The Institute takes no position whether the afore rule stated in $\S 41$ permits examination in the United States of the validity of an act of a foreign state challenged as in conflict with it but calls attention to the fact that in such situations there is no precedent expressly contrary to the possibility that an act so challenged could be examined. ${ }^{22}$

This viewpoint was shared by both Judge Dimock and Judge Waterman in the Sabbatino case. Both judges did not feel inhibited from excluding the application of the Act of State doctrine in a case before them, where the Cuban nationalization measures against American interests were considered as violating recognized principles and rules of international law.

Suffice it to note here that the many expressions of the Executive on the abhorrent and confiscatory character of the Cuban Law No. 851 were considered as freeing the courts from any inhibition to adjudicate the issue of validity and recognition of the Cuban meas-

\footnotetext{
${ }^{30}$ Translations from the pertinent parts of these decisions are to be found in Domke, Indonesian Nationalization Measures before Foreign Courts, 54 AM. J. INT'L L. 313, 315 (1960).

3i Restatement, Foreign Relations LAw of the United States $\$ 41$ comment g (Proposed Official Draft 1962).

${ }^{23} I d$. at $\$ 43$.
} 
ures. In other words: A situation did prevail, similar to that in the second Bernstein case. ${ }^{33}$ There the Nazi government had forced the transfer of title to two merchant ships of plaintiff, a Jewish national of Germany. The Act of State doctrine, excluding a review of the acts of the foreign government, was not applied by the Court after the State Department had notified its policy "to relieve American courts from any restraint upon the exercise of their jurisdiction to pass upon the validity of the acts of Nazi officials." 34 The case was ultimately settled.

Unfortunately, the Executive appears not to share the court's determination in the Sabbatino case that the State Department in various notes and communications on Cuban nationalization "has expressed a lack of concern as to the outcome of the litigation." 35 In the pending proceedings of the Sabbatino case, the Supreme Court of the United States, by an order of November 20, 1962, invited the Solicitor General to express the views of the United States. The latter's Memorandum stated the premise of the Bernstein cases:

[A] court will not examine into the acts of a foreign state affecting property within the latter's territory unless the Executive Branch states, in some formal manner, that it has no objection to such examination.... We take no position at this time as to whether this is a permissible or desirable limitation on the Act of State doctrine. ${ }^{36}$

This, indeed, is not a favorable omen for the protection of property rights of Americans. Anyway, in the event that a writ of certiorari is granted as urged by the Solicitor General, he "will undertake to present a full statement of the position of the Executive Branch and supporting argument upon the merits."37

In a case like Sabbatino, it is the foreign government itself as claimant which seeks to reap the benefits of its nationalization measures with the aid of foreign courts. All the more, the courts should not abdicate their function to determine the private rights of American citizens, irrespective of the attitude the government has

\footnotetext{
ss Bernstein v. Nederlandsche-Amerikaansche Stoomvaart-Maatschappij, 210 F.2d 375 (2d Cir. 1954).

Id. at 376 .

85307 F.2d at 859.

${ }^{30}$ Memorandum for United States on Petition for a Writ of Certiorari, Banco Nacional de Cuba v. Sabbatino, p. 6 (U.S. Supreme Court, October Term 1962, No. 403); reprinted in 2 InTERnAtional Legal Materials 217 (1963).

${ }^{37}$ Id. at 10; 2 International Legal Materials at 221. Meanwhile, certiorari was granted on February 18, 1963, 31 U.S.L. WeER 3255 (U.S. Feb. 19, 1963) (No. 403).
} 
to take, the latter being guided by expediency which may be justified under existing political circumstances. Courts should therefore not be deprived of their essential function to adjudicate issues of private property rights.

\title{
THE LEGAL EFFECT OF GUBAN EXPROPRIATIONS IN THE UNITED STATES
}

\author{
HANS W. BAADE*
}

\section{INTRODUCTION}

The PROBLEM which I propose to discuss is the legal effect of Cuban expropriation measures in the United States. I shall start with the basic assumption that under "normal" conflict of laws rules prevailing in the various states of the United States, title to the properties and contract rights covered by the Cuban expropriation measures is determined by Cuban law. ${ }^{1}$ I shall also assume that the expropriation measures in question have legal validity in Cuba-a point which is hardly open for discussion at this date ${ }^{2}$-and that despite the breaking off of diplomatic relations between the United States and Cuba, the present (Castro) government is the recognized and therefore the lawful government of Cuba, at least in so far as the United States is concerned. ${ }^{3}$

- A.B. 1949, Syracuse University; LL.B., LL.M. 1955, Duke University. Dr. iur. 1951, Privatdozent 1960, University of Kiel, Germany. Diploma, Academy of International Law, The Hague 1956. Associate Professor of Law, Duke University.

${ }^{1}$ Banco Naciónal de Cuba v. Sabbatino, 307 F.2d 845, 854 (2d Cir. 1962); see EHRENZWEIG, CoNflict of LAwS 170-73, esp. 172 (1962).

${ }^{2}$ For a comprehensive discussion of Cuba expropriation legislation, see Garreau de Loubresse, $D e$ quelques éléments de la législation de la République de Cuba en matière d'intervention économique et de nationalisation, 13 REvUE INTERNATIONALE DL Drort Comparé 774 (1961). The development of Cuban constitutional law since the Castro revolution is critically discussed in InTERnational Commission of Jurists, Cuna AND THE RULE OF LAW 78-113 (1962).

${ }^{8}$ In Dade Drydock Corp. v. The M/T Mar Caribe, 199 F. Supp. 871, 874 (S.D. Tex. 1961), it was held that the breaking of formal diplomatic relations between the United States and Cuba "resulted in withdrawal of diplomatic recognition of the Republic of Cuba"; that until such relations were resumed, the defense of sovereign . immunity was not available to Cuba; and that until such resumption of diplomatic 
Since the Cuban expropriation legislation is "normally" applicable by virtue of conflict of laws rules prevailing in the United States, legal recognition of the changes effected by such legislation can only be excluded by exceptional rules restricting or supervening the "normal" ones. It has been contended by authors, and increasingly held by eminent courts, that the "normal" conflict of laws rules are indeed supervened by the appropriate rules of public international law. It has also been held by the Fifth Circuit, ${ }^{4}$ but seemingly not been argued by many writers, that the "normal" rules are similarly supervened by the public policy of the forum. I shall deal with each of these points in turn. But first, of course, we have to dispose of a point which, to the extent that it is pertinent, makes all considerations of international law and of public policy irrelevant. I mean, of course, the Act of State doctrine.

\section{The Agt of State Doctrine}

As formulated by the Supreme Court, this doctrine means that "the courts of one country will not sit in judgment on the acts of the government of another done within its own territory."5 If applicable

relations, "neither the Republic of Cuba nor anyone acting in its behalf had the power to bring suit in this court to assert rights of possession...." In P \& E Shipping Corp. v. Banco Para El Comercio Exterior de Cuba, 307 F.2d 415 (1st Cix. 1962), the First Circuit directed the trial court to ascertain from the State Department, inter alia, the status of the Cuban government in the United States courts during the period of cessation of diplomatic relations. The State Department has of course consistently maintained that the cessation of diplomatic relations with Cuba did not affect the recognition of the government of that country. In response to an inquiry by counsel for defendant in Tabacalera Severiano Jorge, S.A. v. Standard Cigar Company, 311 F.2d 438 (5th Cir. 1962), Marjorie M. Whiteman, Assistant Legal Adviser of the State Department, stated in a letter dated April 15, 1961: "On January 5, 1961, the Government of the United States severed diplomatic and consular relations with the Government of Cuba. This action did not constitute a cessation of recognition of the Government of Cuba. The United States has recognized without interruption, and continues to recognize, as the Government of Cuba, the Government of which Fidel Castro is Premier." Reprinted in Record, p. 49. The State Department has also informed counsel for defendant in the $\mathbf{P}$ \& $\mathbf{E}$ Shipping Corp. case that "In response to the inquiry of the United States District Court for the District of Puerto Rico this Department advised the District Court that the United States continues to recognize as the Government of Cuba the Government of which Fidel Castro is Premier." Letter of Miss Whiteman to Leonard B. Boudin, dated December 20, 1962.

‘Rodriguez v. Pan American Life Insurance Co., 311 F.2d 429 (5th Cir. 1962). But see infra note 35 .

Underhill v. Harnandez, 168 U.S. 250, 252 (1897). See also American Banana Co. v. United Fruit Co., 213 U.S. 347, 357-58 (1909); Oetjen v. Central Leather Co., 246 U.S. 297, 302-03, 303.04 (1918). For a comprehensive discussion, see Note, The 
here, it obviously prevents judicial inquiry into the validity of the Cuban expropriation measures.

It has been asserted that the Act of State doctrine is subject to a limitation-or better, a potential limitation-and to an exception. The limitation, based on the decision of the Second Circuit in the second Bernstein case, is that the Executive can, by a "supervening expression of Executive policy," free the courts from the restraints of the Act of State doctrine. ${ }^{6}$ The exception is based on a controversial reading of the Supreme Court's Act of State doctrine cases ${ }^{7}$ as well as on the decision of the Supreme Court of the Colony of Aden in the Rose Mary case. 8 It holds that the Act of State doctrine is not applicable where the act in question is in violation of international law. This latter exception has been recognized by the District Court in the Sabbatino case, ${ }^{\ominus}$ but abandoned by the Second Circuit. Thus, it presently seems to be without judicial sanction in the United States.

The possible limitation of the Act of State doctrine by executive declaration, on the other hand, is currently at the heart of the dispute. There seems to be some question whether Bernstein II is good law-i.e., whether the Executive can limit the scope of the Act of State doctrine at all. For whatever it may be worth, I regard this point as settled in the affirmative.

The next question-the focal point of the Sabbatino case at the present stage of the proceedings-is whether the Executive has in fact and in the proper form manifested its will that the courts be freed from the restraints of the Act of State doctrine. This depends on the degree of clarity required, and on an appreciation of executive action or inaction in accordance therewith. The Second Circuit has deemed it sufficient that "the State Department has expressed

Act of State Doctrine-Its Relation to Private and Public International Law, 62 Colum. L. REv. 1278 (1962). For a more detailed discussion of the views developed in the text, see Baade, The Expropriation of Foreign Property and the Decline of the Act of State Doctrine, J. Bus. LAw, April, 1968.

- Bernstein v. N.V. Nederlandsche-Amerikaansche Stoomvaart-Maatschappij, 210 F.2d 375, 376 (2d Cir. 1954).

7 Compare Restatement, Foretgn Reiations Law of the United States $\$ 48$, Caveat and Reporter's Note 3 (Proposed Official Draft, 1962), with Metzger, The Act of State Doctrine and Foreign Relations, 23 U. PITT. L. REv. 881 (1962).

${ }^{8}$ Anglo-Iranian Oil Co. v. Jaffrate (The Rose Mary), [1958] 1 Weekly L.R. 246, 248 (Supreme Court, Colony of Aden).

${ }^{\circ}$ Banco Nacional de Cuba v. Sabbatino, 193 F. Supp. 375, 380-82 (S.D.N.Y. 1961), aff'd, 307 F.2d 845 (2d Cir. 1962). 
a lack of concern in the outcome of the litigation." The court held that there has in fact been such an expression of lack of concern. ${ }^{10}$ The Solicitor General, on the other hand, contends that the Executive Branch must state "in some formal manner, that it has no objection" to the examination of the relevant foreign act of state; and he challenges the Second Circuit's finding that there had been such a statement as "erroneous."11 Presumably, this issue will be settled if and when the Supreme Court decides to review the Sabbatino case; ${ }^{12}$ and I feel little temptation here to act as a prophet at this time.

But let us assume that the Second Circuit's decision on the Act of State aspects of the Sabbatino case is upheld. This will meanand has already meant in several subsequent cases decided in the Fifth Circuit-that courts in the United States are now free to adjudicate the validity of the Cuban expropriation decrees. But by what standards are they to be guided in doing so?

II

\section{Public International Law}

Let us start with international law, by all odds the less unruly member of our team of horses, and let us assume that international law still requires some-if not full-compensation for the nondiscriminatory nationalization of the property of aliens, and possibly full compensation for individual and discriminatory expropriations. ${ }^{18}$ Let us further assume that Cuba was not under international law entitled to take the relevant measures as legitimate acts of reprisal, and as of the time of adjudication, is not entitled to valid

\footnotetext{
${ }^{20}$ Banco Nacional de Cuba v. Sabbatino, 307 F.2d 845, 858-59 (2d Cir. 1962).

11 Memorandum for the United States on Petition for a Writ of Certiorari to the United States Court of Appeals for the Second Circuit, Banco Nacional de Cuba v. Sabbatino, pp. 6, 7 (U.S. Supreme Court, October Term, No. 403); also reprinted in 2 INTERNATIONAL LEGAL MATERIALS 212, 216, 217 (1963).

12 Certiorari was granted in Sabbatino on February 18, 1963. 31 U.S.L. WEEK 3259 (Feb. 18, 1963).

${ }^{23}$ See the authorities on both sides of the controversy collected in Banco Nacional de Cuba v. Sabbatino, 307 F.2d 845, at 862-64 (2d Cir. 1962). Note, incidentally, that the present writer did not, in the article cited id. at 864 , assert that adequate compensation is not required by international law. He merely stated that the question was "quite doubtful" with respect to general expropriations, but then went on to assume-without so deciding-that the obligation to pay compensation in such cases still exists, at least as between non-socialist states. Baade, Indonesian Nationalization Measures Before Foreign Courts-A Reply, 54 AM. J. INT'L L. 801, 803-04, 808 (1960). For recent official United States declarations on this question, see infra note 25 .
} 
setoffs or counterclaims. In other words, let us proceed from the premise that the Cuban expropriation measures, so far as they affected the property of aliens, had features which were and are contrary to international law. What are the legal consequences of such irregularities?

The Second Circuit has held in the Sabbatino case that one whose property was expropriated in violation of international law may attack in the United States the validity of the expropriator's title. ${ }^{14}$ In so holding, the court expressly met-or, as I will of course contend, sought to meet-my argument that the wrong under international standards is not in the taking but in the failure to pay compensation for the taking, that international tribunals have never granted restitution of the property taken, and that the expropriator therefore has good title to the property seized, subject to a duty to pay damages. ${ }^{15}$

The court seems to accept these arguments at face value, much to my delight and-at least so I hope-equally to the dismay of mine enemies. ${ }^{18}$ But it goes on to say that national courts also play a part

\footnotetext{
Is Banco Nacional de Cuba v. Sabbatino, 307 F.2d 845, 868 (2d Cir. 1962).

${ }^{15}$ See Baade, supra note 13, at 808.30; Baade, The Validity of Foreign Confiscations: An Addendum, 56 AM. J. INT'L L. 504 (1962).

${ }^{10}$ Especially Domke, Foreign Nationalizations, 55 AM. J. INT'z L. 585, 611-15 (1961); Wortley, Indonesian Nationalization Measures-An Intervention, id. at 680; Mann, Völkerrechtswidrige Enteignungen vor nationalen Gerichten, [1961] Neuk JURISTISCHE WOGHENSCHRIFT 705, 708. Wortley specifically challenges my statement that no international tribunal has ordered specific performance or restitution. He asserts: "The practice of giving specific restitution which was established against Portugal earlier this century in respect of ecclesiastical properties of foreigners is still a normal remedy." Id. at 681 . My reading of the Portuguese Religious Properties cases is to the contrary; see Permanent Court of Arbitration, awards of September 2, 1920, France v. Portugal, 1 R.I.A.A. 1I-14; and Great Britain v. Portugal, id. at 14-16. These cases arose out of the seizure by Portugal, in accordance with a decree of October 8, 1910, of certain properties held in the name of French and British nationals but used by religious corporations. The latter had been dissolved by the decree, and their assets had been declared forfeit to the state. The legahty of the dissolution of the religious corporations and of the confiscation of their assets was not an issue. France and Great Britain claimed that the holding of title for the use of religious corporations was lawful at the time of the acquisition of the properties by their nationals, and that the seizure of the properties therefore constituted an interference with vested rigbts in violation of international law. Both claimant states sought "la restitution ou la valeur" of the properties; and both stated in identical language that they did not question either "la légalité ou ... . la validité, au point de vue du droit interne portugais, des actes du Gouvernement de la République Portugaise." British Observations générales of February 21, 1914, at 6; French Observations générales of January 31, 1914, at 13, 18. Portugal did not dispute the principle of international law on which the claims were based, but contended that the "ownership" of the religious properties by forcign nationals was a sham and a subterfuge to avoid the incidence of the Portuguese mortmain laws. There were altogether 30 claimants (20 French, 10 British), and 28
} 
in the development of international law; that they are competent to grant restitution; and that this remedy-whether it be a feature of international or of domestic law-will often be the only deterrent to violations of international law. ${ }^{17}$

It is difficult to quarrel with a decision which obligingly assents to lay down new law. But I for one doubt whether this holding in Sabbatino will be accepted throughout the world as a new rule of judge-made customary international law. For the court assumes, without any discussion, that it is the individual and not his government who can invoke the protection of international law against foreign confiscations. This, I submit, is quite wrong. Under international law, the United States was entitled to claim reparation from Cuba, be it compensation or restitution. The individual concerned has, at least in the absence of treaty provisions to the contrary, no rights under international law. Consequently, "Mr. Sabbatino" could claim neither compensation nor restitution from Cuba on the basis of international law. ${ }^{18}$

In the Indonesian tobacco case ${ }^{19}$ which I discussed in the article cited by the court, the Netherlands government had at least in a formal note stated that it regarded the expropriations in question to be "absolutely at variance with international law and therefore un-

properties involved (19 held by French nationals, 8 by British nationals, and one held jointly by both). Claims with respect to 5 properties (4 British, 1 French) were dismissed. The panel of the Permanent Court of Arbitration held that "Le Gouvernement de la République Portugaise conservera à titre de propriétaire" 21 of the remaining properties, and awarded lump-sum indemities to the French and British governments. 1 R.I.A.A. at 13-14, 16. The two exceptions concern a chapel and a girls' school held by French claimants. The former had been seized but was not in use at the time of the award, and the latter was still in operation. The Tribunal ordered the chapel, which had been devised to two French nuns (Denise Alis and Marie Solomiac) who under canon law could not hold property, to be "laissée" to them in order to be put at the disposition of the Papal nuncio in Lisbon. With respect to the girls' school, the Tribunal held that it was to be permitted to remain in operation but to revert to Portugal in exchange for an indemnity when no longer used for its present purpose. 1 R.I.A.A. at 14. It seems rather hard to regard the Tribunal's disposition of the AlisSolomiac claim as a "precedent" for anything but the proposition that only in the rarest of instances (here: one out of 23 successful claims) will an international tribunal with power to do so actually order restitution instead of awarding pecuniary compensation.

17907 F.2d at $868-69$.

${ }^{18}$ See the authorities collected in Baade, supra note 19, at 805 n. 28; Note, The Act of State Doctrine-Its Relation to Private and Public International Law, 62 CoLum. L. REv. 1278, 1303.05 (1962).

${ }^{10}$ Oberlandesgericht Bremen, decision of August 21, 1959, 9 ARChIV DEs VölkERRECHTS 318 (1961). 
lawful and invalid."20 Consequently, an identical assertion of a private plaintiff in a German court, even if it came from an improper party, did at least not prejudice the real party in interest. But in the Cuban case, the United States government has never asserted that the expropriations are invalid. It has not even unequivocally stated that it will, contrary to all previous practice, seek restitution instead of compensation. The State Department has called for the customary filing of claims; ${ }^{21}$ and in the Bahia de Nipe litigation, ${ }^{22}$ the Executive has even stated point blank:23

It may be assumed that the confiscation is unlawful under international law, i.e., so far as relations between the Governments of the United States and Cuba are concerned. But that does not mean that Cuba, as between itself and petitioner, does not have valid title to the expropriated property so far as our courts are concerned. It seems rather hard to believe that under these circumstances, a private plaintiff should be entitled to seek a remedy for a public wrong which is not sought by his government.

Let me summarize my comments on the role of international law in this connection. I am prepared to stick by my assertions (1) that acts in violation of international law are not void under the internal law of the actor state; (2) that international law does not regulate the "property" side of territorial expropriations, but merely imposes, in appropriate cases, an obligatio to offer monetary

\footnotetext{
${ }^{20}$ Note of December 18, 1959, official English translation reprinted in 54 AM. J. INT'L L. 484, 485 (1960).

21 Department of State, memorandum of March 1, 1961, reprinted in Kerley, Contemporary Practice of the United States Relating to International Law, 56 AM. J. INT'x L. 165, 166-67 (1962). For a detailed discussion of the position of the United States in the Mexican expropriation controversies, see WOOD, THE MAKING OP THE GOOD NeIGHBor Pourcy 203-59 (1961). This study establishes that subsequent to the adoption of the Good Neighbor policy and especially of its concomitant, non-intervention, the United States did not dispute the legal validity of expropriations of American-owned properties by Latin American states but merely insisted, in appropriate cases, that compensation for such takings be fixed through bilateral diplomatic negotiations. In the light of these carefully documented findings, the analysis of earlier State Department practice by Wetter, Diplomatic Assistance to Private Investment, 29 U. CHI. L. REv. 275 (1962), would seem to be only of historical interest.

${ }^{22}$ Rich v. Naviera Vacuba, 197 F. Supp. 710 (ED. Va. 1961), aff'd, 295 F.2d 24 (4th Gir. 1961); see Note, 1962 Duke L.J. 582.

${ }^{23}$ Memorandum of the United States in Opposition to Application for a stay of United Fruit Sugar Company, September, 1961, reprinted in 1 INTERNATIonAL LEGAL MATERIALS 302 (1962). The arguments advanced by the Executive appear to have been accepted by the Chief Justice of the United States who, on September 14, 1961, denied the application for a stay. See $i d$. at 276, 277. These proceedings have not been published elsewhere.
} 
compensation; and (3) that the standard remedy for "illegal" expropriations is monetary compensation, not restitution. ${ }^{24}$ But even if it should develop that-due to the initiative of the Second Circuit, or otherwise-restitution becomes a standard international law remedy for "illegal" expropriations, this will not alter the picture. It still will be up to the government, not the private litigant, to assert the remedy. The United States, at any rate, seems unlikely to do so. For as spokesmen of the State Department have recently declared on two separate occasions, the United States is now of the opinion that compensation for the taking of American property abroad must be "reasonably adequate and reasonably prompt."25 Since this clearly implies acquiescence in the practice of deferral of payment, it seems hard to believe that after the delay thus indicated, protest will be contended to unsettle changes of title effected in the meantime.

\section{III}

\section{Public Policy}

This, to coin a phrase, is not the end of the matter. Once it is admitted that foreign expropriation legislation which is not protected by the Act of State doctrine can be refused recognition if found to be contrary to the public policy of the forum, it still can be contended that a foreign expropriation in violation of international law is ipso facto contrary to public policy. Where the forum's own nationals are concerned, I find this argnment quite compelling. ${ }^{2 B}$

\footnotetext{
"See Baade, supra note 13, at 830 and passim; Baade, supra note 16, with further references on both sides of the controversies, id. at 504 n.2. This position is further supported by A. A. Fatouros, Government Guarantees to Foreign Investors, 310-13 (1962); Stoll, Völkerrechtliche Vorfragen bei der Anwendung ausländischen Rechts, 4 Berichte Der Deutischen Geselischaft Für Völkerrecht 131, 141-42 (1961). With respect to point (3), see MENZEL, VöLKERRECHT 277, 286-88 (1962). I regretfully part company with our staunchest ally over many years, see Seidl-Hohenveldern, Transformation or Adoption of International Law Into Municipal Law, 12 INT'L \& CoMP. L.Q. 88, 94 (1963).

${ }^{25}$ Ball, American Business Abroad, 46 DeP'T STATE But.. 912, 914 (1962); Chayes, The Lawyer and the Alliance for Progress, 47 id. 192, 195 (1962): “The right to take private property is implicit in sovereignty. Our own Constitution recognizes it. And the United States has long conceded that other countries have the right to expropriate property, including that of Americans, provided they offer just compensation, that is, compensation that is reasonably adequate and reasonably prompt."

${ }^{26}$ See Seidl-Hohenveldern, Reprisals and the Taking of Private Property, 9 NETHERLANDS INTERNATIONAL LAw Review 470, 476 (special issue 1962): "If it is not against the public policy of the forum to recognize a title 'won' by robbing an innocent citizen
} 
We have now reached the topic of public policy. As my Lord Burrough said, "it is a very unruly horse, and once you get astride it you never know where it will carry you." ${ }^{27}$ Let us see briefly where it has carried the Fifth Circuit.

On October 17, 1962, the Fifth Circuit decided three cases involving Cuban expropriations. The leading case, Rodriguez v. Pan Am̌merican Life Ins. Co., ${ }^{28}$ is an action under life insurance policies issued to Cubans in Cuba by a Louisiana company with a branch office in Havana. The branch office had been nationalized and the Cuban state substituted as the obligor of all policies outstanding in Cuba, but the company did not stress this defense here. Instead, it argued that the policyholders were "proscribed nationals." They had occupied positions of importance under the Batista regime, and early in 1959, their properties had been declared forfeit to the Cuban State.

As already mentioned, the Fifth Circuit followed the lead of the Second Gircuit in holding that by virtue of what is here termed the consistent, repeated, and current position of the State Department, the Act of State doctrine does not apply to Cuban expropriations. ${ }^{2 \theta}$ But obviously, the proscription decrees here set up in defense were not in violation of international law, as they were aimed only at Cuban nationals. Nevertheless, the Court of Appeals directed the District Court to determine "whether the Cuban decrees are conflscatory or whether the particular decrees are otherwise violative of fundamental concepts of justice, and, therefore, without status, in these particular cases." 30 In other words, the court held the confiscation of an alien's property by the state, of his own nationality within the territory of such state to be violative of the forum's public policy. ${ }^{31}$

The second case decided on October 17, Mendendez v. Aetna Life Ins. Co., concerns a "proscribed national" whose property in Cuba

of the forum in order to 'punish' him for what his State i.e., the very State of the forum, has 'done'-what is the public policy clause good for?"

az Richardson v. Mellish, 2 Bing. 229, 252, 130 Eng. Rep. 294, 303 (C.P. 1824). For an illuminating discussion of the subject, see Kahn-Freund, Reflections on Public Policy in the English Conflict of Laws, 39 The Crotius SocietY, Transactions 39 (1954).

28311 F.2d 429 (5th Cir. 1962).

${ }^{20} \mathrm{Id}$. at 437 .

${ }^{80} \mathrm{Id}$. at 436 .

"1 But see note 35 infra. 
was insured with defendant. ${ }^{32}$ The loss occurred before the proscription, but the appraisal was made after plaintiff had sought refuge in the United States. Acting under the proscription decree, the Cuban government called upon the company to pay the assessed damages to it; such payment was in fact effected through the sale of part of the company's assets kept on deposit in Cuba as security for policies written there. Nevertheless, the Fifth Circuit summarily reversed the lower court's dismissal of the action "for reasons stated in" Rodriguez.

The third case, Tabacalera $v$. Standard Cigar Co., arose out of the "intervention" of the Cuban cigar industry. ${ }^{33}$ Tobacco had been shipped by Tabacalera before the intervention, but the purchase price became due thereafter. Plaintiff, a Cuban refugee who was the sole owner of Tabacalera, sued to recover the purchase price. The District Court dismissed, but the Fifth Circuit reversed, again referring to Rodriguez.

There are some parallel cases in the Florida state courts, ${ }^{34}$ and there also is a subsequent decision of the Fifth Circuit, ${ }^{36}$ but $I$ will

\footnotetext{
sa Menendez v. Aetna Ins. Co., 311 F.2d 437 (5th Cir. 1962). The facts are not stated in the opinion, but have been reconstructed from the record and counsel's briefs, which were made available to us.

s Tabacalera Severiouno Jorge, S.A. v. Standard Cigar Co., 311 F.2d 438 (5th Cir. 1962). Again, the facts are reconstructed from the record and from counsel's briefs.

" Jorge v. Antonio Co., 19 Fla. Supp. 101 (Circuit Court, Hillsborough County, 1961) (same plaintiff as in Tabacalera, supra note 33, but another defendant); Lorido v. Pan American Life Ins. Co., 19 Fla. Supp. 167 (District Court, Dade County 1962); Raij v. Pan American Life Ins. Co., 19 Fla. Supp. 162 (District Court, Dade County 1962).

${ }^{85}$ Pan American Life Ins. Co. v. Inocencio Blanco, 311 F.2d 424 (5th Cir. 1962). Appellee, a Cuban national who had purchased three annuity policies from appellant in Cuba, brought suit on these policies in the United States. Appellant company pleaded, inter alia, that Cuba had expropriated not only its properties in Cuba, but also specifically substituted, by Cuban legislation, the Republic of Cuba as the obligor, under all policies outstanding in Cuba. With respect to this latter defense, the Fifth Circuit stated:

This Court ... applied the legal principles enunciated in Judge Waterman's opinion in Sabbatino to actions by Cuban nationals now residing in the United States for the cash surrender value of policies issued by Pan American; held that "Our courts are not compelled by the Act of State Doctrine to give force and effect to the decrees of the Castro government in Cuba"; and reversed orders dismissing the complaints and remanded the cases to the District Court for determining, upon development of all the facts, whether the Cuban decrees involved were confiscatory and violative of the principles of international law "and therefore without status in these particular cases." $I d$. at 428.

It would seem that the court is here interpreting Rodriguez (supra note 4, discussed supra text at notes 28-31), as being decided on grounds of international law, not public policy. This would seem to pose a curious paradox. For only the American com-
} 
not trouble you with these. It seems that the public policy issue is raised in its classical form in the three cases decided on October 17. The Act of State doctrine does not apply, but neither does international law. Once you accept the proposition-quite doubtful to me in the life insurance cases-that the "proper" law is Cuban, Cuban law will govern unless its applicability is excluded by the public policy of the forum. If the public policy of the forum indeed con. demns all foreign confiscations irrespective of the nationality of the victims, as the Fifth Circuit has expressly indicated, our problem is solved. Either the Act of State doctrine applies and the confiscation is recognized, or the Act of State doctrine does not apply and the consfication is not recognized. The rule is, of course, broad enough to cover the Sabbatino case, without the necessity of recourse to international law.

\section{IV}

\section{Federal and State Law}

This brings me to the last point which I propose to discuss. How do you square these holdings on the Act of State doctrine and on public policy with Erie ${ }^{36}$ and Klaxon? ? $^{37}$ Both Sabbatino and Rodriguez have held that the Act of State doctrine is not a rule of international law..$^{38}$ Of course it is not, for otherwise we would have an international full faith and credit clause for governmental actions, which obviously does not exist. Besides, where the act in question involves a violation of international law, one has some difficulty in visualizing the acting state as earnestly claiming that the victim must accept and give effect to the illegal act.

But if the Act of State doctrine is not a rule of public international law, what is it? Sabbatino and Rodriguez tell us that it is a rule of the conflict of laws. ${ }^{3 \theta}$ If so, then under Erie-Klaxon, it is applicable in a federal court only where the state in which the court

pany, not the Cuban plaintiff, is entitled to the protection of international law. But instead of invoking such protection (if, indeed, individuals can do so, see supra at note 18 and sources there referred to), the "aggrieved" party is relying on the international delinquency.

${ }^{36}$ Erie R.R. v. Tompkins, 304 U.S. 64 (1938).

${ }^{37}$ Klaxon Co. v. Stentor Elec. Mfg. Co., 313 U.S. 487 (1941). The problem discussed in the text is briefly adverted to in Banco Nacional de Cuba v. Sabbatino, 307 F.2d 845, 869 n. 16. See also Note, The Act of State Doctrine-Its Relation to Private and Public International Law, 62 ColUM. L. Rev. 1278, 1296.97 (1962).

s8 307 F.2d at $855 ; 311$ F.2d at 434 .

${ }^{89}$ Ibid. 
sits has incorporated the rule into its law. This is the case in New York and in Florida-with the Bernstein II limitation at least in the latter state-and, to judge by a hurried look into "Sheperds," also in Indiana, Massachusetts, New Jersey, Texas, and Oregon.

Suppose a state has no decision in point. Then a federal court sitting there would presumably be free to assume that the state court would in all probability follow the lead of the other states and recognize the Act of State doctrine.

But suppose a state court expressly rejects the Act of State doctrine. Here, in my opinion, Klaxon fails. Under 28 U.S.C. $\$ 1257$, there will be no certiorari from the decision of the state court of last resort, because there is no violation of the Constitution, a federal statute, or a treaty. On the other hand, I, for one, would maintain that a federal court sitting in a state which has rejected the Act of State doctrine still has to give effect to it. For the doctrine is, in my opinion, not only a rule of the conflict of laws, but also a rule of judicial abstention, laid down by the Supreme Court of the United States for the entire federal judiciary.

Consequently, as a practical matter we may conclude that the Act of State doctrine will be in danger only where there is either no diversity or where the object in controversy is less than $\$ 10,000$. In all other cases arising in "doubtful" states, one of the parties will remove.

Now as to public policy: national or state? Judicially determined or declared by the executive? It seems clear that in line with Belmont, Pink, and Kolovrat, ${ }^{40}$ a federal court will give effect to an express executive determination of public policy. Specific authority in point would seem to be Bernstein II.41 Where there is no

\footnotetext{
${ }^{10}$ United States v. Belmont, 301 U.S. 324, 331-32 (1937); United States v. Pink, 315 U.S. 203, 233 (1942); Kolovrat v. Oregon, 366 U.S. 187, 198 (1961).

12 In Bernstein II, the State Department had declared that: [T] consistently opposed the forcible acts of dispossession of a discriminatory nature practiced by the Germans on the countries or peoples subject to their controls," and that: "[T]he policy of the Executive, with respect to claims asserted in the United States for the restitution of identifiable property (or compensation in lieu thereof) lost through force, coercion, or duress as a result of Nazi persecution in Germany, is to relieve American courts from any constraint upon the exercise of their jurisdiction to pass upon the validity of the acts of Nazi officials." The court, faced with this declaration, permitted the plaintiff to allege matters otherwise barred by the Act of State doctrine. Bernstein v. N.V. Nederlandsche-Amerikaansche Stoomvaart-Maatschappij, 210 F.2d 375,376 (2d Cir. 1954). Thereupon, the case was settled, so that, strictly speaking, there never was a decision as to the legal effect, if any, of the first part of the declaration here quoted.
} 
countervailing federal public policy, a federal court would also probably give effect to a clearly expressed state public policy.

But where do you find such a policy, and how do you shape a federal rule of public policy where there is no express state public policy and no executive declaration? ${ }^{42}$ The issue is complicated even where, as in New York, you have state court decisions on public policy in the field of expropriations. For all of these decisions, so far as I can determine, proceed from the assumption that the Act of State doctrine is applicable. Take, for instance, the case of Kleve v. Basler Lebens-Versicherungs-Gesellschaft In Basel. ${ }^{43}$ The facts are about on all fours with some of the Cuban insurance cases, especially with Menendez, where the insurance company had actually paid the confiscating government. In the Kleve case, Mr. Justice Peck held:

As for the very obnoxious and offensive character of the German decrees, the court is obliged to hold that governing law is no less controlling because it is bad law. The plaintiffs shift the point when they argue that our courts will not enforce foreign law contrary to our own public policy. This is not a case of enforcing German law here but rather of necessarily recognizing the force of German law in Germany. Certainly, our courts would not enforce the German law by applying it to the assets of these plaintiffs in this country, but we cannot undo or set at naught what has been done by the German government with the assets of the parties in Germany. ${ }^{44^{-}}$

\footnotetext{
42 See Banco Nacional de Cuba v. Sabbatino, 307 F.2d 845, 859 (2d Cir. 1962): "The right to just compensation in return for property taken by the government is certainly well established in American jurisprudence. It is even protected by the Constitution, Amend. V. Therefore, it is likely that any taking of one's property without provision for adequate compensation is contrary to the public policy of this forum.... But we are aware of the admonition that public policy is an 'unruly horse.' The concept has proved to be a very difficult one to confine when one seeks to apply it. We are not entirely certain what the American public would consider to be the proper policy of the United States with respect to expropriation of the property of aliens by foreign sovereigns when the property has its situs within the foreign countries. Also, decision of this case based upon the public policy of this forum is undesirable because reliance upon such a basis for decision results in a nationalistic, or municipal, solution of a problem that is clearly international." But see United States v. Belmont, 301 U.S. 324, 332 (1937): "The public policy of the United States relied upon as a bar to the action is that declared by the Constitution, namely, that private property shall not be taken without just compensation. But the answer is that our Constitution, laws and policies have no extraterritorial operation, unless in respect of our own citizens.... What another country has done in the way of taking over property of its nationals, and especially of its corporations, is not a matter of judicial consideration here. Such nationals must look to their own government for any redress to which they may be entitjed."

${ }_{43} 182$ Misc. 776, 45 N.Y.S.2d 882 (S. Ct., N.Y. County 1943).

44 Id. at $782 ; 45$ N.Y.S.2d at 887.
} 
But he went on to quote authorities couched in Act of State terms. Would he have shaped a different rule if he had felt to be free from the restraints of the Act of State doctrine? I do not know, and neither do I know what the Fifth Circuit would have done in the Menendez case if Kleve had been a Florida, not a New York decision.

I will conclude with this confession of ignorance. I hope to have presented you with some of the questions, and am now eager to listen to answers. 